\title{
Современные закономерности формообразования жилых планировочных единиц
}

\author{
И.Г.Федченко, НИИТИАГ, Москва; СФУ, Красноярск
}

В статье обобщены закономерности развития урбанизированных территорий крупных городов, влияющие на возникновение новых форм жилых планировочных единиц в начале XXI века. Даётся характеристика современных принципов формообразования жилых территорий. Приводятся материалы натурного обследования, результаты анализа литературных источников, проектных предложений, наиболее выразительных примеров современных жилых планировочных единиц. Констатируется, что в настоящее время проблемы социальной стратификации, сегрегации, миграционных процессов, а также нарастающая динамика функциональной трансформации, формирование ландшафтно-экологического мировоззрения общества приводят к видоизменению морфологии жилых территорий. В мировую практику архитектуры и градостроительства проникают новейшие планировочные типы жилой среды, разные по содержанию и структуре. Категории «мобильность»и «доступность» являются основными в обеспечении нормального функционирования современного города. Динамика функциональных процессов рождает появление многофункциональных жилых ядер в крупном городе. Стремление к разнообразию форм жизнедеятельности формирует жилые единицы смешанных типов застройки. Развитие ландшафтно-экологического мировоззрения и возникновение эколого-ориентированных инициатив формируют жилые образования по типу «сообщество сообществ», по структуре представляющих собой группу локальных образований, связанных системой общественных пространств, где окружение человека создаёт образовательную среду, направленную на формирование экологической культуры, новых образов мышления. В современных городах происходит сближение транспорта, мест приложения труда и жилья, внедряются концепции совмещения коммерчески-активной зоны с транспортно-пересадочным узлом. В статье делается вывод о необходимости учёта современных закономерностей развития урбанизированных территорий и, как следствие, возникновении новых форм жилых планировочных единиц в проектировании и реконструкции жилых территорий нашей страны ${ }^{1}$.

Ключевые слова: жилые планировочные единицы, жилая среда, градостроительство.

Исследование выполнено за счет средств Государственной программь Российской Федерации «Развитие науки технологий» на 2013-2020 годы в рамках плана фундаментальных научных исследований Минстроя России и PAACH, тема 1.6.3.

\section{Modern Patterns of Formation of Residential Planning Units}

I.G.Fedchenko, NIITIAG, Moscow; SFU, Krasnoyarsk

The article analyzes the tendency of the development of urbanized areas of large cities, affecting the emergence of new forms of residential planning units at the beginning of the XXI century. The characteristic of modern principles of shaping residential areas is analyzed. Article is based on the materials of the author's field study, on the results of the analysis of literary sources, design proposals of the most expressive examples of modern residential planning units. The problems of social stratification, segregation, migration processes, as well as the growing dynamics of functional transformation, the formation of landscape-ecological worldviews of society lead to a modification of the morphology of residential areas. The latest planning types of the living environment, different in content and structure, spread into the world practice of architecture and urban planning. The categories of "mobility" and "accessibility" are fundamental in ensuring the normal functioning of a modern city. The dynamics of functional processes gives rise to the emergence of multifunctional residential cores in a large city. The trend towards diversity of daily living activities forms residential units of mixed types of buildings. The development of a landscape-ecological worldview and the emergence of ecooriented initiatives form residential communities of the "multiple communities" type, which in structure constitute a group of local entities connected by a system of public spaces, where the human environment creates an educational environment aimed at creating an ecological culture. In modern cities there is a connecting of transport, places of application of labor and housing, the concepts of combining a commercial-active zone with a transport and transfer hub are being introduced. The article concludes that it is necessary to take into account modern tendencies of development of urbanized territories and, as a result, the emergence of new forms of residential planning units in the design and reconstruction of residential areas of Russia.

Keywords: residential planning units, residential environment, urban planning.

В последнее десятилетие в практике отечественного градостроительства происходит возврат к комплексному формированию жилых территорий. Массовое жилищное строительство в нашей стране связано с микрорайонной моделью застройки, несмотря на легитимное уравнивание в Градостроительном 
кодексе элементов планировочной структуры - микрорайона и квартала. Анализ проектирования и строительства жилых планировочных единиц за рубежом также демонстрирует комплексный подход к организации жилых территорий.

Жилые планировочные единицы возникли в теории и практике градостроительства как реакция на поиск идей рационального планирования развития крупного города. Так, под влиянием уплотнения исторических кварталов, укрупнения их размеров за счёт включения социальных объектов в жилую среду сложились концепции формирования жилых территорий массового строительства: микрорайон в СССР, нейборхуд в Америке и коммьюнити ${ }^{1}$ в Европе. На протяжении XX века они проходили апробацию строительством, после чего их жёсткая функционалистская «конструкция» вызвала критику, сейчас эволюционируют под действием закономерностей развития общества, формируются их новые версии. В настоящее время активно анализируются результаты международного эксперимента микрорайонирования в полном смысле. Анализ динамики цитирования работы Кларенса Перри о нейборхуде показал, что уровень академического цитирования работы в журналах с высоким импакт-фактором в период с 2000-2015 год возрос приблизительно в десять раз (в 2000 году зафиксировано 25 цитирований, в 2015-ом - 200) [11].

Появляются публикации, анализирующие отечественный опыт строительства микрорайонов, опыт создания микрорайонов на постсоветском пространстве, и поиск новых путей развития [1-3; 7-10; 13; 14]. В связи с этим целесообразно проследить современные закономерности формообразования жилых планировочных единиц, которые демонстрируют их способность к дальнейшему развитию.

В философии закономерность - это относительно устойчивые и регулярные взаимосвязями между явлениями и

В тексте статьи используются заимствованные определения: «нейборхуд» - от англоязычного термина «neighborhood-unit» («единица соседствующих»), «коммьюнити» - от англоязычного термина «сommunity» («сообщество»), как закреплённые в российской практике термины. объектами реальности, обнаруживающиеся в процессах изменения и развития. Закономерности урбанизированных территорий, диктующие новые формы жилой среды проявляются в развитии многофункциональности, разнообразии форм жизнедеятельности, росте мобильности и потребности в социальной и физической доступности. В начале XXI века проблемы социальной стратификации, сегрегации, миграционных процессов, а также нарастающая динамика функциональной трансформации, формирование ландшафтно-экологического мировоззрения общества приводят к видоизменению морфологии жилых территорий. В мировую практику архитектуры и градостроительства проникают новейшие планировочные типы жилой среды, разные по содержанию и структуре.

\section{Динамика формирования многофункциональных жилых ядер в крупном городе}

Динамичный образ жизни начала XXI века диктует новые критерии формирования жилых территорий в современном городе. Развиваются идеи смешанного использования территории, включения транспортно-пересадочных узлов в жилые территории; разнообразие и эффективность становятся основообразующими при развитии жилых территорий. Многофункциональные жилые планировочные единицы как «ядра роста» крупного города появляются в рамках нового строительства, а также реконструкции. Так, например, вокруг территории Корвин Бульвара (условное название территории площадью в 22 га, на которой с начала 1990 гг. осуществляется комплексная реконструкция центральной части Будапешта), последовательно формируются смешанные кварталы. Этот проект является основным объектом в рамках плана городского обновления 8-го округа Будапешта, являющимся частью крупнейшей программы по обновлению городов в Центральной Европе (рис. 1, 2).

Состояние реконструируемой территории неоднозначно: с одной стороны приходящая в упадок ветхая застройка и развитая инфраструктура зданий - с другой. Проектное

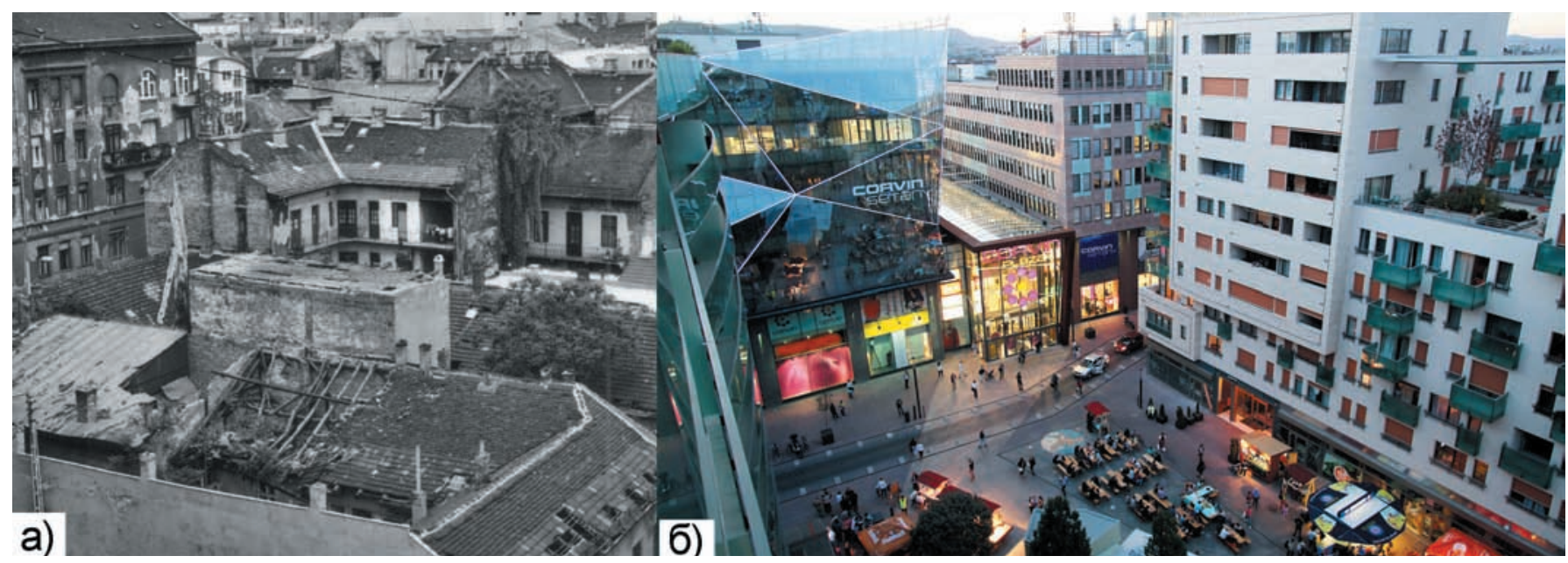

Рис. 1. Вид на реконструируемую территорию Корвин Бульвар. Будапешт. Венгрия: а) до реконструкции; б) после комплексной регенерации (источник: Rév8 Plc. Corvin-Szigony Project. - Режим достуna: http://rev8.hu/english/by-us/) 

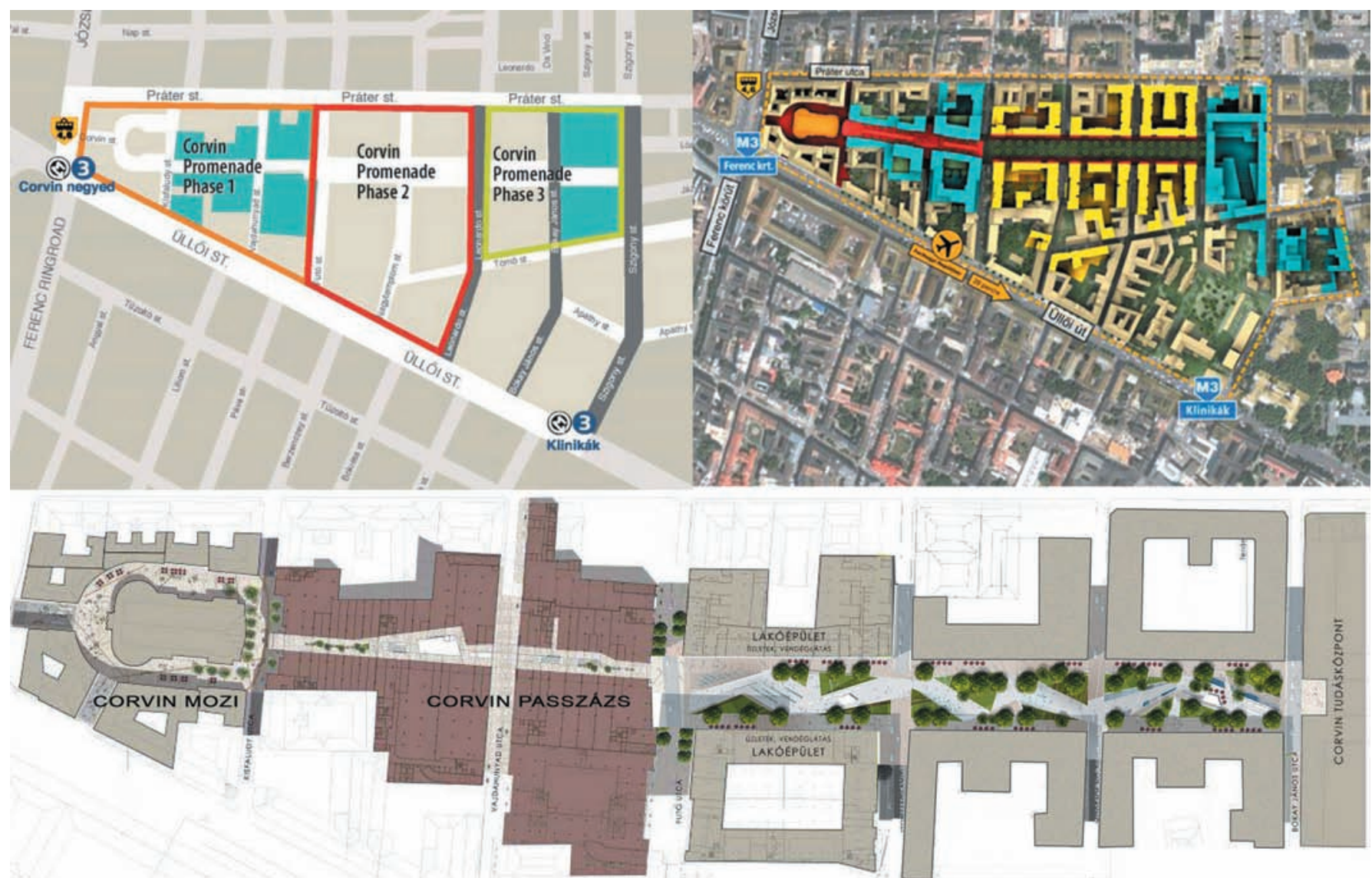

Puc. 2. Схемы комплексного развития района Корвин Бульвар (источник: Rév8 Plc. Corvin-Szigony Project. - Pежим достуnа: http://rev8.hu/english/by-us/)

решение территории Корвин Бульвар следует стратегии государственно-частного партнёрства и стилю жизни в Будапеште. Эта стратегия привела к созданию оживлённого, многофункционального района с населением около 4000 человек, с рабочими местами, большой торговой, деловой зонами и зонами сервиса и отдыха, который посещает 8 миллионов человек в год. Стратегическим преимуществом района, использованным в проекте, является его расположение - в

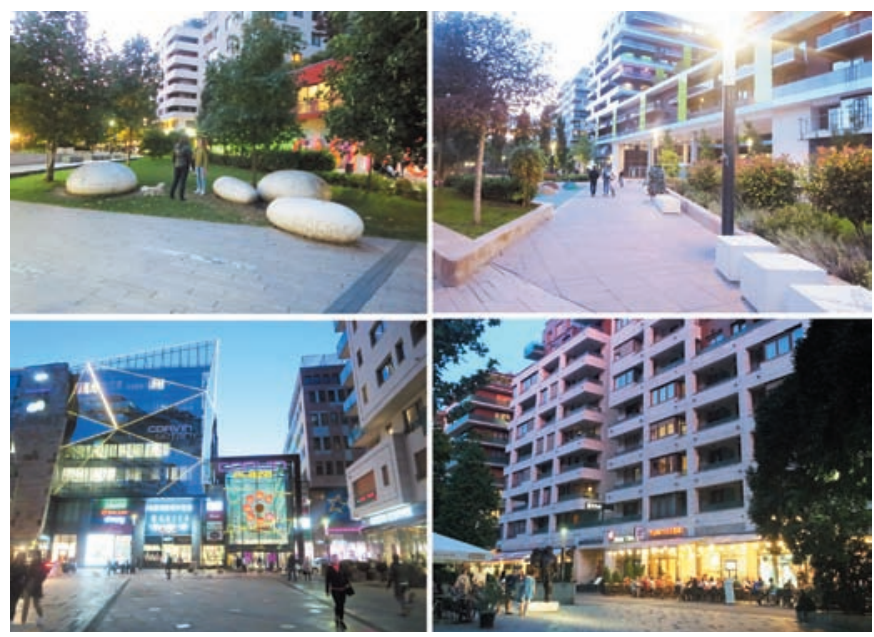

Рис. 3. Многофункциональное пешеходное пространство в районе Корвин Бульвар. Фото И.Г. Федченко. 2019 год пешеходной доступности находятся городская библиотека, институты, научный и культурный центр, торговые комплексы, кроме того, есть предложения сформировать научный парк. В жилой застройке расширяется функциональное наполнение нижнего яруса, вызванное усложнением пространственной организации культурно-досуговой, хозяйственно-бытовой и производственной деятельности вследствие интенсификации территорий. Можно констатировать, что в случае интеграции рабочих мест в жилую среду функционально-смешанный район можно трактовать как микроэкономическую единицу. Хотя проект завершён только на 60\%, в районе Корвин Бульвар уже создано новое «гражданское сердце» города, и он стал фактором развития для окружающей территории (рис. 3).

Для эффективного и гибкого функционирования во времени смешанных районов в проектах предусматривается «незаконченность проекта», дающая возможность «адаптации» и «приспособляемости» территории к новым возникающим функциональным потребностям.

\section{Стремление к разнообразию форм жизнедеятельности}

\section{и, как следствие, типов жилой застройки}

В начале XXI века в городах складываются новые разнообразные формы организации жизнедеятельности населения. Сегодня территории, прилегающие к жилой застройке, используются по-разному - совмещаются с местами приложения 
труда, имеют многофункциональный характер использования земли, вплоть до ведения домашнего сельского хозяйства и фермерства. Проекты жилых планировочных единиц включают территории смешанных типов застройки: от индивидуального дома до многосекционного, объединённого общественным пространством. Стремление к разнообразию форм жизнедеятельности и, как следствие, типов жилой застройки проявляется как в рамках комплексной модернизации жилых микрорайонов 1960-1970-х годов строительства $[3 ; 7 ; 8 ; 10 ; 13-15 ; 18]$ так и в новейших проектах жилых планировочных единиц. Так, например, территория комплексного развития Ридберг во Франкфунте (ФРГ) представляет собой соединение разных по архитектурному типу жилых кварталов, объединённых системой рекреации. Ридберг, являющийся крупнейшим районом на окраине Франкфурта-на-Майне и одним из крупнейших жилищных проектов в Германии, расположен в восьми километрах от города в северо-западном направлении. В 1997 году было принято решение о создании на севере Франкфурта жилого района, с размещением различных форм проживания и деятельности. Планируется что к 2020 году в Ридберге будет возведено около 6000 жилых домов с населением около 16 000 человек. Кроме того, жителям этого района будет предоставлено 8000 рабочих мест (особенно это касается кампуса франкфуртского филиала Университета Гёте) (рис. 4, 5, 6).

Ридберг состоит из нескольких кварталов, некоторые из которых уже завершены. Кварталы различаются по своим функциям и конструктивным характеристикам жилой застройки: квартал Риденберг Вест Винг (юго-восток) - состоит из индивидуальных и террасных домов не выше пяти этажей и имеет смешанный характер локальных сообществ-кондоминимумов со своими общественными пространствами; кварталы Альткёнигблик (к северо-западу) и Бонифациумбруннен (северо-восток) состоят из двухквартирных домов, таунхаусов, кондоминиумов, городских вилл, кооперативного жилого комплекса, домов для инклюзивного проживания; квартал на восточном склоне - Шонеаустич - состоит из индивидуальных, блокированных домов, таунхаусов с территориями садоводства и огородничества; центральный квартал улицы Розы Люксембург сформирован многосекционными домами смешанного типа, торговыми центрами, рынком, медицинским центром; отдельно спланирован кампус университета Гёте [12].

К 2020 году район должен быть завершён, включая культурно-бытовую, социальную инфраструктуру государственных образовательных учреждений, в том числе более десяти детских садов, две начальные школы, среднюю школу, а также церковные пространства и места приложения труда.

Стремление к разнообразию форм жизнедеятельности диктует появление новых форм жилой застройки современного города.

Создание коммуникативной эколого- и социальноориентированной жилой среды

В начале XXI века в градостроительном планировании жилых территорий складывается тенденция к формированию ланд- шафтно-экологического мировоззрения. Среди современных проектов можно выделить группу эко-ориентированных проектов жилых образований, по структуре представляющих собой группу

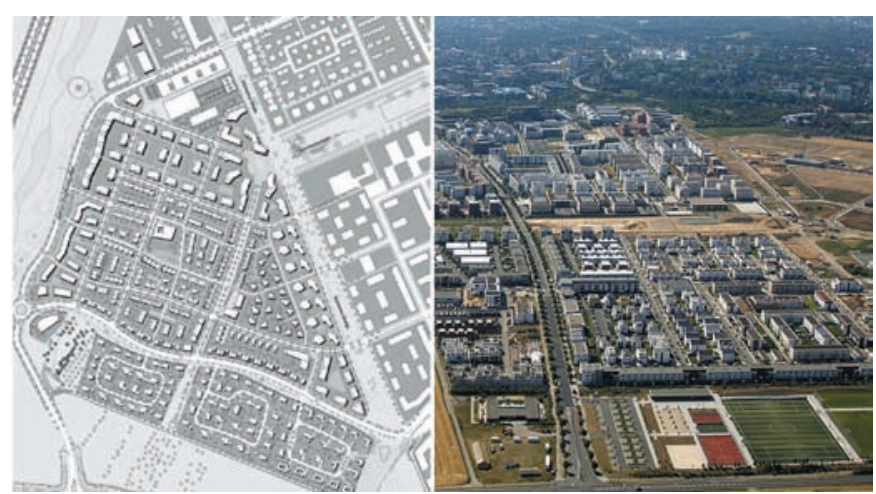

Рис. 4. Общий вид и схема генерального плана района Ридберг во Франкфурте. ФРГ [12].

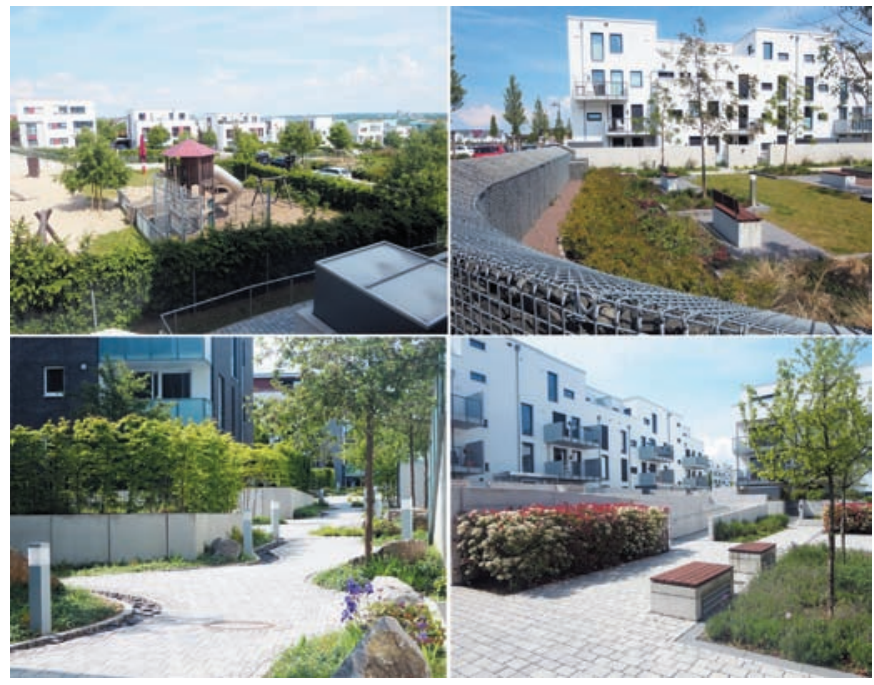

Pис. 5. Вид на квартал Риденберг Вест Винг в районе Ридберг (юго-восток). Фото И.Г. Федченко. 2019 год

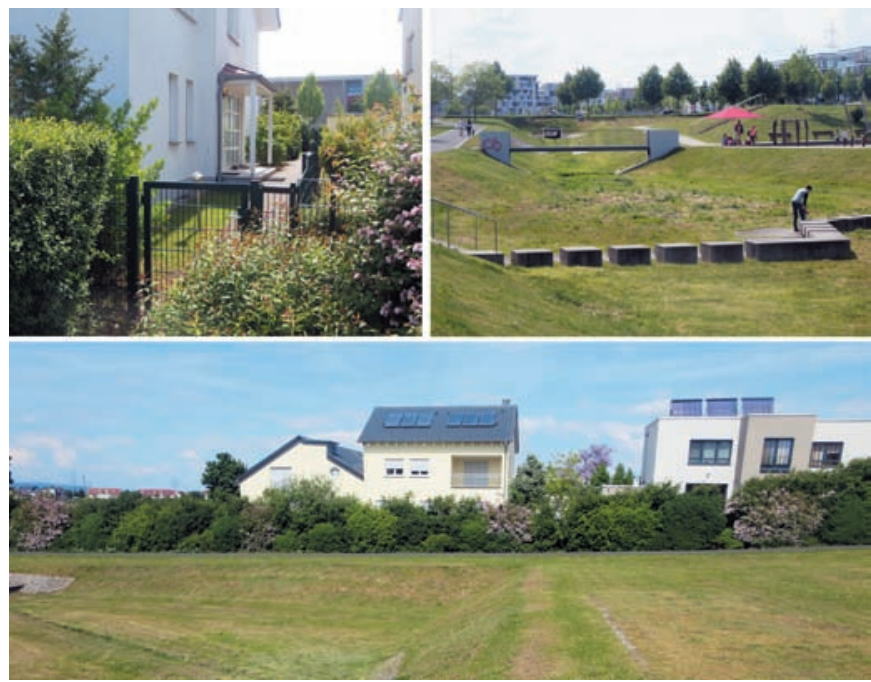

Рис. 6. Вид на квартал Альткёнигблик в районе Ридберг. Фото И.Г. Федченко. 2019 год 
локальных образований, связанных системой общественных пространств, где окружение человека должно создавать образовательную среду, направленную на формирование экологической культуры, новых образов мышления, творческих инициатив. Так, например, эко-ориентированный район Виикки в Хельсинки имеет международную известность не просто как энергоэффективный объект, но как постоянно действующая архитектурно-строительная и социальная лаборатория, начавшая свою деятельность в 2000 году (рис. 7). Проект создания эко-сообщества был принят в результате конкурса, организованного в 1994 году. Победителем назван проект под девизом «60¹5" северной широты» архитектора Петри Лааксонена за счёт уникальности предложенных планировочного решения и экологических принципов $[4,5]$.

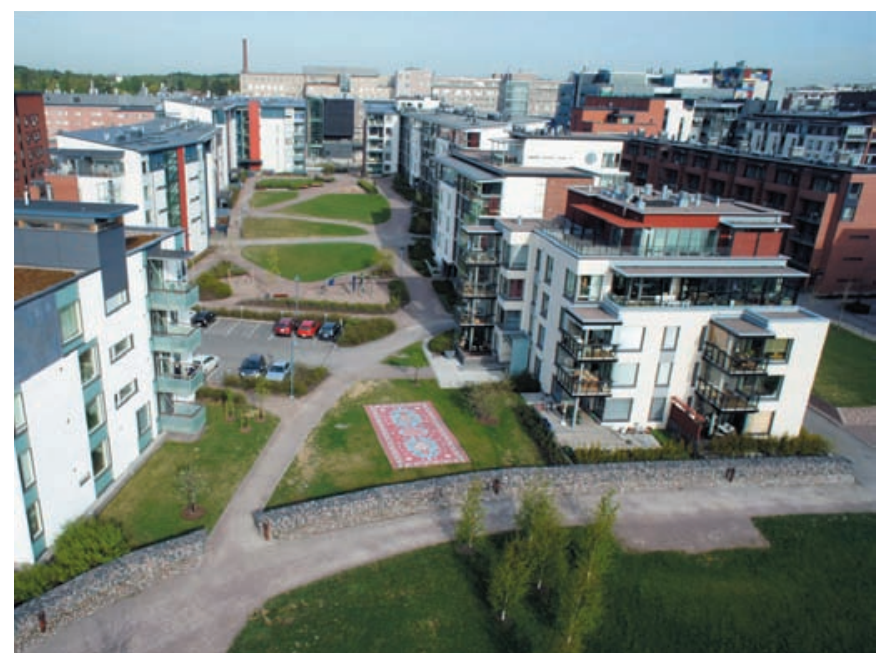

Рис. 7. Виикки - жилой экорайон Хельсинки. Финляндия (цитируется по: [4])

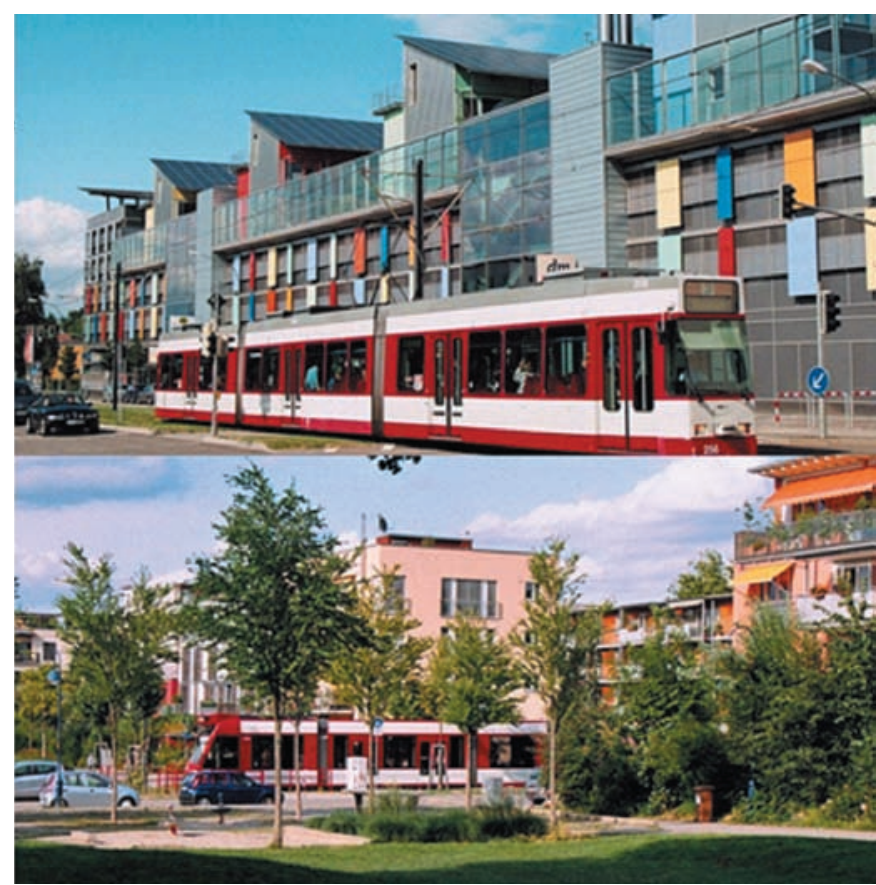

Рис. 8. Концепция транзитно-ориентированного района (TOD). Район Ваубан, Фрайбург-им-Брайсгау, Германия (цитируется по: [6])
В соответствии с планом Виики жилые группы разделены пешеходными променадами, и абсолютно каждое домовладение имеет прямой выход в зелёную зону. Разработка детального плана закончена в 1995 году и принята в департаменте градостроительства в Хельсинки $[4,5]$.

\section{Динамика развития процессов мобильности и доступности в городах}

В зарубежных странах с начала XXI века с целью сближения мест проживания и работы внедряются концепции совмещения коммерчески-активной зоны с транспортным узлом. Целью подобного развития является обеспечение мобильности и доступности: предоставление возможности связи с городом, с целью уменьшения зависимости от личного автомобиля за счёт использования мультимодальных систем общественного транспорта. Этому способствует не только приближенность жилой застройки к общественному транспорту, но и лёгкость смены маршрута. Развитие жилых территорий учитывает создание комфортных условий для пешеходов: оборудование удобных пешеходных переходов, создание многофункциональной сети общественных объектов и пространств. Образуется тип жилой планировочной единицы с явно выраженной плотностью функций транспортного общественно узла, расположенного в геометрическом центре жилого образования. В США система транспортно-ориентированного развития считается концепцией, диаметрально противоположной традиционному структурированию городов на основе нейборхудов, где остановки общественного транспорта расположены на границах планировочной единицы. В транзитно-ориентированном районе центр в радиусе 400-800 м окружён относительно плотной застройкой в зоне пешеходной доступности, по мере удаления от которого плотность застройки уменьшается (рис. 8). Система транзитно-ориентированного проектирования внедрена во многих штатах Америки, появляется в Европе и в планировочных концепциях жилой среды микрорайонов в России [6].

\section{Формирование комбинированных версий жилых пла- нировочных единиц}

Как показывает анализ градостроительных планов планировочных единиц, формообразование новейших современных морфотипов представляет собой комбинацию их первоначальных концепций: «микрорайон-квартал», «микрорайонкоммьюнити», «микроарйон-нейборхуд»

В России происходит комбинирование дискретных и периметральных форм по принципу «микрорайон-квартал»: в проектах микрорайонов последнего десятилетия становится популярным мелкоячеистый рисунок плана за счёт внедрения кварталов в структуру жилой планировочной единицы. В связи с нарастанием темпов социальной стратификации и социально-территориальной сегрегации современных городов формируются обособленные жилые комплексы по социально-экономическому признаку - разделённые по 
рыночной стоимости жилья. Обособленность выражается в установлении физических барьеров жилых комплексов в микрорайонах, разграничивающих жилую среду на внешнюю - «чужую», и внутреннюю - «огороженную» (как правило, доступ к внутренней закрыт). Комбинирование идеи микрорайона и квартальной планировки приводит к разделению территории внутримикрорайонными проездами, формирующими кварталы, увеличению плотности транспортной сети, утрате принципа непрерывности пешеходного движения и сети зелёных рекреационных пространств, нарушению физической доступности социально гарантированных объектов. Территория микрорайона становится небезопасной и малодоступной для маломобильных групп населения и подрастающих поколений, способствует обострению проблемы парковки личных автомобилей. Об этом свидетельствует ряд проектов в Москве и регионах. Так, например, в Красноярске за последнее время появился целый ряд подобных проектов: микрорайоны «Сити», «Малые кварталы», «Преображенский», «Новоостровский» и др. (рис.9).

В Европе реконструкция сложившихся микрорайонов происходит по принципу «микрорайон-коммьюнити»: в проектах реновации заложен принцип формирования локальных сообществ. Так, например, вновь реконструируемые микрорайоны в Дрездене (Горбитц, Пролис), в Берлине (Матцан, Хеллерсдорф) представляют собой цельные жилые территории, состоящие из архитектурных групп, формирующих сообщества жителей, находящихся в непрерывной взаимосвязи. В аморфные пространства микрорайонов свободной планировки, образованные однотипными панельными жилыми зданиями, включены жилые группы различных архитектурных типов, что способствует смешению проживания семей разного достатка [8]. Новые жилые планировочные единицы представляют собой локальные образования с активным периметром, интегрированным в городскую структуру. В Китае, согласно исследованиям Дауфанна Лу $[16 ; 17]$, происходит соединение концепции микрорайона и нейборхуда в едином морфотипе: происходит процесс деления территории микрорайона на образования меньшего порядка - соседства индивидуального домостроения. Плотность новообразования зависит от применяемых архетипов застройки. Характерной особенностью данного морфотипа «микрорайон-нейборхуд» является сохранение социальных гарантий в виде предоставления доступа к социально значимым объектам в пешеходной доступности. Так, например, в 2002 году Ду Ли предложил объединить концепции «Микрорайон» и «Нейборхуд»в комбинированном образовании. Проект микрорайона Ровер Палас (Rover Palace) архитектурной группы «GZ Architects» в городе Ченгу (2000-2002) предусматривает расположение периметральной застройки средней этажности, объединённой системой общих пространств и индивидуальных домовладений. Мотивация соединения концепций микрорайона и нейборхуда обусловлена тем, что идея микрорайона наиболее полно реализует социальные гарантии жилой среды в обеспечении объектами образования начальной и средней ступени, здравоохранения, рекреации и их безопасной пешеходной доступности, а идея нейборхуда состоялась как единица административного управления (рис. 10). В США прослеживается стремление к комбинированию идей нейборхуда и коммьюнити через активизацию местного сообщества. В проектах нейборхудов внедряется принцип локализации границ и формирования совместных мероприятий на открытых пространствах, а также в специализированных коммьюнити-центрах. Усиливается принцип планирования развития собственных жилых территорий по принципу «снизу-вверх».

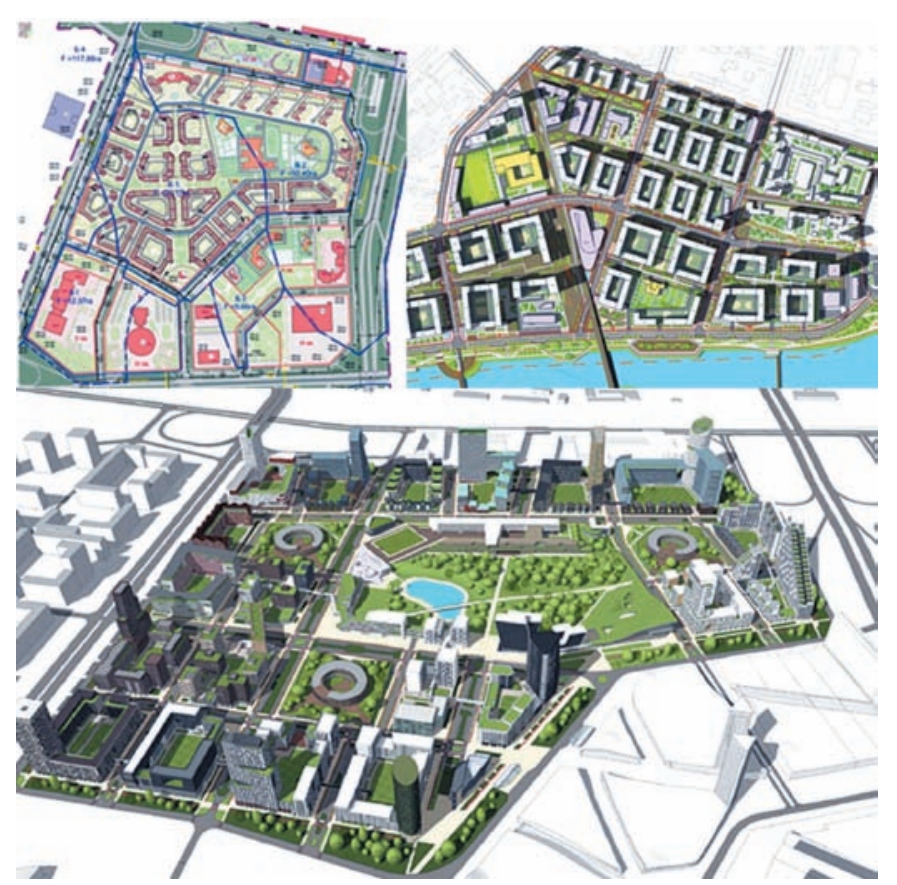

Puc. 9. Схемы проектов планировок микрорайонов в рамках комбинированных версий «микрорайон-квартал». Красноярск: а) микрорайон «Преображенский» (разработан в Территориальном градостроительном институте «Красноясркгражданпроект»); б) микрорайон «Новоостровский» (разработан в архитектурной фирме «Проектдевелопмент»); в) микрорайон «Сити» (разработан в архитектурной фирме «А-2»))
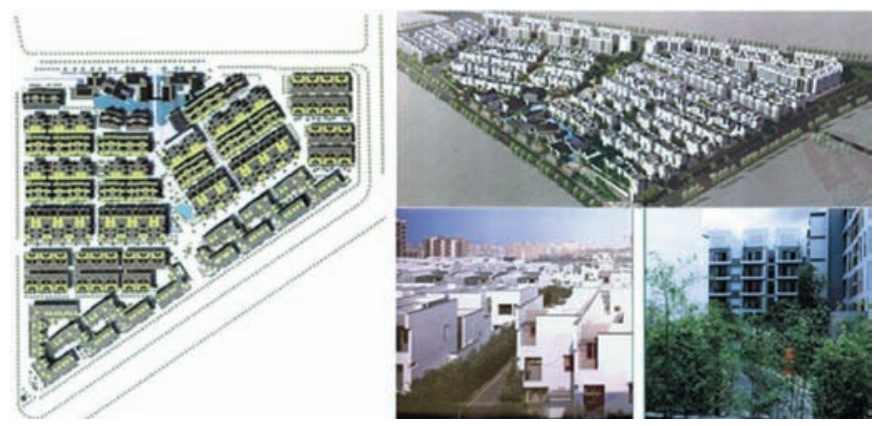

Рис. 10. Интегрированный «микрорайон-нейборхуд» «Пятый сад». Город Шеньжень, Китай [17] 


\section{***}

Закономерности развития урбанизированных территорий в начале XXI века, связанные с проблемами социальной стратификации, сегрегации, миграционных процессов, а также нарастающей функциональной интеграции производственной деятельности в жилые структуры, формирование ландшафтно-экологического мировоззрения общества приводят к видоизменению морфологии жилых территорий. Так, динамика функциональных процессов рождает появление многофункциональных жилых ядер в крупном городе; стремление к разнообразию форм жизнедеятельности формирует жилые единицы смешанных типов застройки. Развитие ландшафтноэкологического мировоззрения и возникновение экологоориентированных инициатив формируют жилые образования по типу «сообщество сообществ». Рост мобильности и доступности в городах влияет на сближение транспорта, мест приложения труда и жилья. В целом происходит формирование комбинированных версий жилых планировочных единиц. Необходимо учитывать вышеперечисленные закономерности формообразования жилых планировочных единиц при создании новых проектов планировок жилищного строительства и реконструкции существующих микрорайонов в нашей стране.

\section{Лuтература}

1. Красильникова, Э.Э. Современные тенденции формирования гибких и устойчивых жилых образований / Э.Э. Красильникова, В.А. Русанов, Л.А. Кузина // Вестник Волгогр. гос. архит.-строит. ун-та. Сер.: Стр-во и архит. - 2014. - Вып. 36 (55). - С. 275-283.

2. Крайняя, Н.П. Массовая жилая застройка городов России: между Западом и Востоком / Н.П., Крайняя // Современная архитектура мира. Вып.1 / Отв. ред. Н.А. Коновалова. - М., Спб : Нестор-История. - 2011. - 44-51 с.

3. Кукина, И.В. Регламенты «свободного развития» урбанизированных территорий в планируемом создании агломераций в зарубежных странах / И.В. Кукина // Academia. Архитектура и строительство. - 2011. - № 3. - С. 81-86.

4. Кукина, И.В. Теоретические и методические подходы к эколого-ориентированной реконструкции крупных городов в зарубежных странах / И.В. Кукина. Отчет по НИР; ЦНИИП Минстроя РОССИИ НИИТИАГ, 2015. - С. 5.

5. Камалова, К.В. Современные модели городской жилой среды на примере Хельсинки (Финляндия) / К.В. Камалова // Современная архитектура мира. Вып.10. - 2018. - № 1. - С. 172-188.

6. Птичникова, Г.А. Новые морфотипы архитектурного пространства современных городов / Г.А. Птичникова, А.В. Антюфеев // Социология города. - 2014. - № 2. - С. 5-9.

7. Федченко, И.Г. К вопросу о трансформации и развитии жилых планировочных единиц крупного города в начале XXI века // И.Г. Федченко // Academia. Архитектура и строительство. - 2014. - № 4. - С. 87-93.

8. Федченко, И.Г. Микрорайон на постсоветском пространстве: социально-планировочные изменения и тенденции развития / И.Г. Федченко // Известия вузов. Строительство. - 2012. - № 1. - С. 108-115.;

9. Чуй, Я.В. К вопросу о некоторых тенденциях изменения общественных пространств городов в конце XX - начале XXI веков / Я.В. Чуй // Academia. Архитектура и строительство. - 2015. - № 4. - C. 125-128.

10. Javier, M. Modernist housing estates in European cities of the Western and Eastern Blocs / M. Javier, D. M. Carmen // Planning Perspectives. - 2016. - № 31 (4). - P. 533-562.

11. Perry, C.A. The Neighborhood Unit. Neighborhood and Community Planning / Perry C.A. // National municipal review. - New York: Committee for the Regional Survey of New York and its Environs, 1929.

12. Kaufmann, C. Der Frankfurter Riedberg: Stadtentwicklung für das 21 / C. Kaufmann, P. Michael. - Berlin : Jahrhundert Jovis. - 2018. - $240 \mathrm{~s}$.

13. Karin, W. Large-Scale Housing Estates in Central and East European Cities: Between Residential Preferences and Local Housing Market Differences // Housing, Theory and Society. 2011. - № 4 (28). - P. 410-431.

14. Karien Dekker. Residential Satisfaction in Housing Estates in European Cities: A Multi-level Research Approach / Karien Dekker, Sako Musterd, Sjoerd de Vos, Ronald van Kempen // Housing Studies. - 2011. - № 4 (26). - P. 479-499.

15. Kukina, I.V. Morphological Development of the Microdistricts under the Pressure of the Post-socialist Transformations: Case Studies of Siberian Cities / I.V. Kukina, I.G Fedchenko // Proceedings of the «International Conference on Cities and Change: Three Decades of Post-socialist Transition 1989-2019»; Scientific Editors: Nebojša Camprag, Anshika Suri. - TU prints, TU Darmstadt, Germany, 2019. - 137-147 pp.

16. Lu, D. Travelling urban form: the neighborhood unit in China / D. Lu // Planning Perspectives. - 2006. - № 21. - P. 369-392.

17. Lu, D. Remaking Chinese Urban Form: Modernity, Scarcity and Space, 1949-2005 / D. Lu. - Routledge, London, 2005. - 360 p.

18. Metspalu, $P$. Revisiting the role of architects in planning large-scale housing in the USSR: the birth of socialist residential districts in Tallinn, Estonia, 1957-1979 / P. Metspalu, B.H. Daniel // Planning Perspectives. - 2018. - №33. - Pp. 335-361.

\section{Reference}

1. Krasil'nikova E.E. Sovremennye tendentsii formirovaniya gibkikh i ustoichivykh zhilykh obrazovanii [Current trends in the formation of flexible and sustainable residential entities]. Vestnik Volgogr. gos. arhit.-stroit. un-ta. Ser.: Str-vo $i$ arhit. [Journal of Volgograd University. Construction and architecture], 2014, Is. 36 (55), pp. 275-283. (In Russ., abstr. in Engl.).

2. Krajnyaya N.P. Massovaya zhilaya zastroika gorodov Rossii: mezhdu Zapadom i Vostokom [Mass residential development of Russian cities: between the West and the East]. In N.A. Konovalova (ed.) Sovremennaya arhitektura mira [Modern architecture of the world], Is.1. Moscow, Saint Petersburg, NestorIstoriya Publ., 2011, pp. 44-51. (In Russ., abstr. in Engl.). 
3. Kukina I.V. Reglamenty «svobodnogo razvitiya» urbanizirovannykh territorii $\vee$ planiruemom sozdanii aglomeratsii $\vee$ zarubezhnykh stranakh [Regulations for the "free development" of urban areas in the planned creation of agglomerations in foreign countries]. Academia. Arhitektura $i$ stroitel'stvo [Academia. Architecture and construction], 2011, no. 3, pp. 81-86. (In Russ., abstr. in Engl.).

4. Kukina I.V. Teoreticheskie i metodicheskie podkhody k ekologo-orientirovannoi rekonstruktsii krupnykh gorodov $v$ zarubezhnykh stranakh [Theoretical and methodological approaches to ecologically oriented reconstruction of large cities in foreign countries], Otchet po NIR; CNIIP Minstroya Rossii , 2015, p. 5.

5. Kamalova K.V. Sovremennye modeli gorodskoi zhiloi sredy na primere Khel'sinki (Finlyandiya) [Modern models of urban living environment on the example of Helsinki (Finland)]. Sovremennaya arhitektura mira [Modern architecture of the world], Is.10 (1/2018), pp. 172-188. (In Russ., abstr. in Engl.)

6. Ptichnikova G.A., A.V. Antyufeev. Novye morfotipy arkhitekturnogo prostranstva sovremennykh gorodov [New morphotypes of the architectural space of modern cities]. Sociologiya goroda [Sociology of the city], 2014, no. 2, pp. 5-9. (In Russ., abstr. in Engl.)

7. Fedchenko I.G. K voprosu o transformatsii i razvitii zhilykh planirovochnykh edinits krupnogo goroda $v$ nachale XXI veka [ $0 \mathrm{n}$ the issue of transformation and development of residential planning units of alarge city at the beginning of the XXI century]. Academia. Arhitektura i stroitel'stvo [Academia. Architecture and construction], 2014, no. 4, pp. 87-93. (In Russ., abstr. in Engl.)

8. Fedchenko I.G. Mukroraion na postsovetskom prostranstve: sotsial'no-planirovochnye izmeneniya $i$ tendentsii razvitiya [Microdistrict in the post-Soviet space: socio-planning changes and development trends]. Izvestiya vuzov. Stroitel'stvo [University news. Construction], 2012, no. 1, pp. 108-115. (In Russ., abstr. in Engl.)

9. Chuj Ya.V. K voprosu o nekotorykh tendentsiyakh izmeneniya obshchestvennykh prostranstv gorodov $v$ kontse
$X X$ - nachale XXI vekov [On the question of some trends in the changing public spaces of cities in thelate XX - early XXI centuries]. Academia. Arhitektura i stroitel'stvo [Academia. Architecture and construction], 2015, no. 4, pp. 125-128. (In Russ., abstr. in Engl.)

10. Javier M., Carmen D.M. Modernist housing estates in European cities of the Western and Eastern Blocs. Planning Perspectives, 2016, no. 31 (4), pp. 533-562.

11. Rerry C.A. The Neighborhood Unit. Neighborhood and Community Planning. National municipal review. New York, Committee for the Regional Survey of New York and its Environs Publ., 1929.

12. Kaufmann C., Michael P. Der Frankfurter Riedberg: Stadtentwicklung für das 21. Berlin, Jahrhundert Jovis, 2018, 240 s.

13. Karin W. Large-Scale Housing Estates in Central and East European Cities: Between Residential Preferences and Local Housing Market Differences. Housing, Theory and Society, 2011, no. 4 (28), pp. 410-431.

14. Karien Dekker. Residential Satisfaction in Housing Estates in European Cities: A Multi-level Research Approach. Housing Studies, 2011 no. 4 (26), pp. 479-499.

15. Kukina I.V., Fedchenko I.G. Morphological Development of the Microdistricts under the Pressure of the Post-socialist Transformations: Case Studies of Siberian Cities. Proceedings of the "International Conference on Cities and Change: Three Decades of Post-socialist Transition 1989-2019", Nebojša Camprag, Anshika Suri (eds.). TU prints, TU Darmstadt, Germany, 2019, pp. 137-147.

16. Lu D. Travelling urban form: the neighborhood unit in China. Planning Perspectives, 2006, no. 21, pp. 369-392.

17. Lu D. Remaking Chinese Urban Form: Modernity, Scarcity and Space, 1949-2005. Routledge, London, 2005, 360 p.

18. Metspalu P., Daniel B.H. Revisiting the role of architects in planning large-scale housing in the USSR: the birth of socialist residential districts in Tallinn, Estonia, 1957-1979. Planning Perspectives, 2018, no. 33, pp. 335-361.

Федченко Ирина Геннадьевна (Красноярск). Кандидат архитектуры. Старший научный сотрудник Научно-исследовательского института теории и истории архитектуры и градостроительства (филиал ФГБУ «ЦНИИП Минстроя России») (111024, Москва, ул. Душинская, 9. НИИТИАГ); доцент кафедры градостроительства Института архитектуры и дизайна ФГАОУ В0 «Сибирский федеральный университет» (660041, г. Красноярск, пр. Свободный, 79. СФУ). Эл.почта: ifedchenk@inbox.ru.

Fedchenko Irina Gennadievna (Krasnoyarsk). Candidate of Architecture, Senior Researcher at the Research Institute of Theory and History of Architecture and Urban Planning (branch of TsNIIIP Minstroy of Russia) (9 Dushinskaya St., Moscow, 111024. NIITIAG), Associate Professor at the Department of Urban Planning of Institute of Architecture and Design of Siberian Federal University (79 Svobodny pr., Krasnoyarsk, 660041, SFU).E-mail: ifedchenk@inbox.ru. 